\title{
THE
}

\section{SEASONAL DISTRIBUTION AND ABUNDANCE OF FISHES AND DECAPOD CRUSTACEANS IN A CAPE COD ESTUARY}

\author{
Kenneth W. Able \\ Michael P. Fahay \\ Kenneth L. Heck Jr. \\ Charles T. Roman \\ University of Rhode Island, roman@uri.edu \\ Mark A. Lazzari
}

See next page for additional authors

Follow this and additional works at: https://digitalcommons.uri.edu/gsofacpubs

Terms of Use

All rights reserved under copyright.

\section{Citation/Publisher Attribution}

Able, K. W., Fahay, M. P., Heck, K. L., Jr., Roman, C. T., Lazzari, M. A., \& Kaiser, S. C. (2002). SEASONAL DISTRIBUTION AND ABUNDANCE OF FISHES AND DECAPOD CRUSTACEANS IN A CAPE COD ESTUARY. Northeastern Naturalist, 9(3), 285-302. doi: 10.1656/1092-6194(2002)009[0285:SDAAOF]2.0.C0;2 Available at: https://doi.org/10.1656/1092-6194(2002)009[0285:SDAAOF]2.0.C0;2

This Article is brought to you for free and open access by the Graduate School of Oceanography at DigitalCommons@URI. It has been accepted for inclusion in Graduate School of Oceanography Faculty Publications by an authorized administrator of DigitalCommons@URI. For more information, please contact digitalcommons-group@uri.edu. 
Authors

Kenneth W. Able, Michael P. Fahay, Kenneth L. Heck Jr., Charles T. Roman, Mark A. Lazzari, and Susan C. Kaiser

This article is available at DigitalCommons@URI: https://digitalcommons.uri.edu/gsofacpubs/386 


\section{BioOne

\section{SEASONAL DISTRIBUTION AND ABUNDANCE OF FISHES AND DECAPOD CRUSTACEANS IN A CAPE COD ESTUARY}

Author(s): Kenneth W. Able, Michael P. Fahay, Kenneth L. Heck

Jr., Charles T. Roman, Mark A. Lazzari, and Susan C. Kaiser

Source: Northeastern Naturalist, 9(3):285-302.

Published By: Eagle Hill Institute

https://

doi.org/10.1656/1092-6194(2002)009[0285:SDAAOF]2.0.CO;2

URL: http://www.bioone.org/doi/

full/10.1656/1092-6194\%282002\%29009\%5B0285\%3ASDAAOF

$\% 5 \mathrm{D} 2.0 . \mathrm{CO} \% 3 \mathrm{~B} 2$

BioOne (www.bioone.org) is a nonprofit, online aggregation of core research in the biological, ecological, and environmental sciences. BioOne provides a sustainable online platform for over 170 journals and books published by nonprofit societies, associations, museums, institutions, and presses.

Your use of this PDF, the BioOne Web site, and all posted and associated content indicates your acceptance of BioOne's Terms of Use, available at www.bioone.org/page/terms of use.

Usage of BioOne content is strictly limited to personal, educational, and non-commercial use. Commercial inquiries or rights and permissions requests should be directed to the individual publisher as copyright holder. 


\title{
SEASONAL DISTRIBUTION AND ABUNDANCE OF FISHES AND DECAPOD CRUSTACEANS IN A CAPE COD ESTUARY
}

\author{
Kenneth W. Able ${ }^{1}$, Michael P. Fahay ${ }^{2}$, Kenneth L. Heck, JR. ${ }^{3}$, \\ Charles T. Roman ${ }^{4}$, Mark A. Lazzari ${ }^{5}$, and Susan C. Kaiser ${ }^{1}$
}

ABSTRACT - Sampling in several habitat types (sand/mud, eelgrass, sand, gravel, macroalgae/mud) during all seasons with a variety of gears in Nauset Marsh, Massachusetts during 1985-1987 found a fauna consisting of 35 fish and 10 decapod crustacean species. Although most of the abundant species were found in several habitat types, species richness and habitat use appeared to be highest for vegetated habitats (eelgrass, macroalgae). The fishes and decapods were numerically dominated by cold-water taxa; however, numerous fish species, represented by rare individuals of predominantly southern forms, enriched the fauna. Species composition of Nauset Marsh could be distinguished from estuaries south of Cape Cod and even from the south shore of the cape. Both fishes and decapods were most abundant during the summer, apparently due to the contributions from spring and summer spawning in the estuary and the adjacent Atlantic Ocean. The location of Nauset Marsh and other estuaries on Cape Cod provide a unique opportunity to evaluate the importance of this region as a faunal boundary to estuarine species.

\section{INTRODUCTION}

For several decades it has been accepted that nearly two thirds of the coastal fishery resources in the U.S. are estuarine dependent (McHugh 1966; but see Able and Fahay 1998 for discussion of this term). Although often repeated, this generalization has seldom been critically reevaluated even though the extent, nature and focus of our fisheries have changed since the time of that estimate. A revised estimate, based on U.S. commercial fishery landings, indicated that $77 \%$ by weight ( $71 \%$ by economic value) of commercially important fishes were dependent on estuaries for reproduction, nurseries, food production, or migration (Chambers 1992). In this same analysis, a much lower percentage (32\%) was considered estuarine dependent in the northeastern U.S. Our understanding of the extent and patterns of utilization of estuarine nurseries in the northeast extends beyond general faunal surveys for

\footnotetext{
${ }^{1}$ Marine Field Station, Institute of Marine and Coastal Sciences, Rutgers University, Tuckerton, NJ 08087; able@imcs.rutgers.edu. ${ }^{2}$ NOAA/National Marine Fisheries Service, Highlands, NJ, 07732; mike.fahay@noaa.gov. ${ }^{3}$ Marine Environmental Sciences Consortium and University of South Alabama, Dauphin Island, AL 36528; kheck@ jaguar1.usouthal.edu. ${ }^{4}$ U.S.G.S. Patuxent Wildlife Research Center, University of Rhode Island, Narragansett, RI 02882; charles_roman@usgs.gov. ${ }^{5}$ State of Maine, Department of Marine Resources, West Boothbay Harbor, ME 04575; mark.lazzari@state.me.us.
} 
only a limited number of estuaries (Able and Fahay 1998, Conover and Ross 1982, Haedrich and Haedrich 1974, Lazzari and Tupper 2002, Nixon 1982, Oviatt and Nixon 1973, Pearcy and Richards 1962, Teal 1986, Werme 1981). Other studies have begun to examine habitat use by estuarine fishes in more detail including zoogeographic (Ayvazian et al. 1992) and temporal (Able and Fahay 1998; Jeffries and Johnson 1974; Rountree and Able 1992, 1993) comparisons. Despite this progress, we need more extensive and intensive observations of the patterns (see Underwood et al. 2000) of faunal use of estuaries over a broad latitudinal range to more fully understand the role they play in our fisheries.

To this end, we report on the seasonal distribution patterns for fish and decapod crustaceans by habitat type for a Cape Cod estuary, Nauset Marsh, Massachusetts. These observations are designed to complement prior faunal studies in Nauset Marsh that have focused on Zostera marina L. (eelgrass ) communities (Heck et al. 1989), habitat use by Urophycis tenuis (Mitchill) (juvenile white hake) (Fahay and Able 1989), Homarus americanus H. Milne Edwards (juvenile American lobster) (Able et al. 1988), the life history of Myoxocephalus aenaeus (Mitchill) (grubby) (Lazzari et al. 1989), and estimates of secondary production (Heck et al. 1995).

\section{STUDY SITE AND HABITATS}

Nauset Marsh is a shallow (ranges to $5 \mathrm{~m}$ depth, most $<2 \mathrm{~m}$ ), 950hectare barrier island estuary on the outer edge of Cape Cod with direct exchange through an inlet to the Atlantic Ocean (Fig. 1). Tidal range was about $1.5 \mathrm{~m}$ just inside the inlet and less in other parts of the system due to frictional attenuation (Aubrey and Speer 1985). During 1985-1987 salinity ranged from 24 to $34 \%$ and temperature from -2 to $27^{\circ} \mathrm{C}$. Freshwater input is predominantly by groundwater seepage (Portnoy et al. 1998).

The major habitat types were mapped with true color vertical aerial photographs (scale 1:18,000; date October 22, 1982) (Roman et al. 1990). Short-form Spartina alterniflora Loiseleur (smooth cordgrass) marsh $(35 \%$ of the area), tidal kettle ponds, and shallow $(<3 \mathrm{~m})$ tidal channels $(33 \%)$ make up most of the system. Other habitats include intertidal mudflats $(12 \%)$ often dominated by patches ofthe green alga Cladophora sericea (Huds.) Kutz, intertidal sandflats (11\%) and eelgrass beds $(6 \%)$. Additional habitats of minor areal extent but with potential ecological importance include peat reefs (Able et al. 1988, Roman 1988) and drift algae. Primary production by eelgrass (Roman and Able 1988) and total macrophytes (Roman et al. 1990) has been studied extensively. A list of fish species encountered in this system were included in the tabulations of Middle Atlantic Bight estuaries by Able and Fahay (1998). 


\section{MATERIALS AND METHODS}

Extensive sampling throughout the Nauset Marsh complex began in August 1985 and continued through June 1987. Qualitative ichthyoplankton sampling, to determine the reproductive seasonality of the species spawning and utilizing Nauset Marsh, occurred from December 1985 through June 1987. Preliminary sampling was conducted with an epibenthic sled, a $0.5-\mathrm{m}$ hoop net, and 20 -cm bongo nets, all with $0.505-$ $\mathrm{mm}$ mesh. The tows were variable in duration until standardized tows of 5

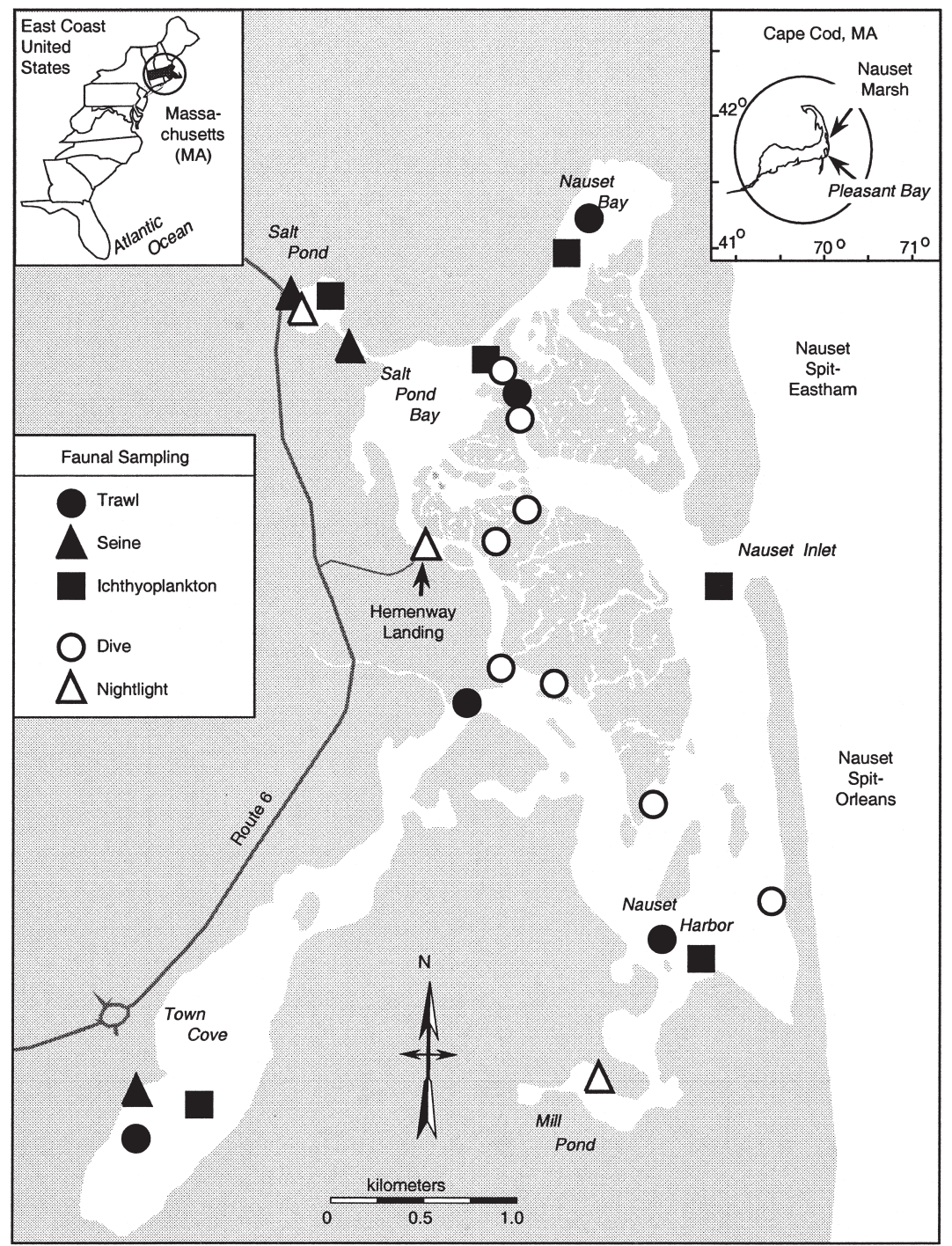

Figure 1. Sampling locations in Nauset Marsh, Cape Cod, MA. 
min with the 20-cm bongo nets were conducted between September 1986 and June 1987. Six locations were sampled in September and October 1986 and March, April, May, and June 1987 (Fig. 1). Additional samples were collected near Nauset Inlet on flood and ebb tides and during the day and night at Nauset Harbor and Town Cove stations. These collections were made in all the above months except March. In addition, 17 nightlight samples were collected during each sampling period from June - September 1986 and seven samples from May-August 1987 from Mill Pond, Town Cove, Hemenway Landing, and Salt Pond (Fig. 1). For these samples, we illuminated the water surface after dark for 30 to 60 minutes with a battery-powered 50-watt light bulb and collected larval and juvenile fishes attracted by the light with a dip net.

Sampling in benthic habitats was conducted with trawls and seines and in a variety of habitats characteristic of the Nauset Marsh system during August, October, and December 1985 and April, June, July, September, and October 1986 (Fig. 1, Table 1) to characterize the fish and decapod fauna as completely as possible. At most habitats several types of gear were used to more fully characterize the fauna. In deeper habitats an otter trawl (4.9 m with 0.6-cm cod end mesh) was towed for two minutes. Based on sampling in August 1985 we determined that four two-minute replicate tows at each habitat type were appropriate to characterize the fauna, based on species accumulation curves (Heck et al. 1989). Replicate samples were kept separate, sorted live, and returned to the system, except for species of interest, which were preserved in $10 \%$ formalin. All decapod crustaceans and fishes were identified, counted, and measured. The information for deep eelgrass habitat (e.g., Heck et al. 1989) is also included here to provide complete data for all habitats. At intertidal and subtidal habitats three replicate seine $(7.5 \mathrm{~m}$ with $0.6-\mathrm{cm}$ mesh) collections were made by sweeping over the study site while one end of the seine remained stationary at the water's edge. All decapod crustaceans and fishes were identified and enumerated, a representative subsample was measured and then all animals were returned to the system.

Table 1. Sampling effort and physical characteristics for the major habitats sampled in the Nauset Marsh system.

\begin{tabular}{|c|c|c|c|c|c|c|}
\hline Habitat & $\begin{array}{c}\text { Sampling } \\
\text { Gear }\end{array}$ & $\begin{array}{c}\text { Number of } \\
\text { Samples }\end{array}$ & $\begin{array}{c}\text { Mean Water } \\
\text { Depth }(\mathrm{m})\end{array}$ & $\begin{array}{c}\text { Dominant } \\
\text { Vegetation }\end{array}$ & $\begin{array}{c}\text { Temperature } \\
\text { Range }\left({ }^{\circ} \mathrm{C}\right)\end{array}$ & $\begin{array}{c}\text { Salinity } \\
\text { Range }(\% o)\end{array}$ \\
\hline \multirow[t]{2}{*}{ Eelgrass } & trawl & 41 & 2.0 & Zostera marina & $4.0-16.5$ & $26-30$ \\
\hline & seine & 18 & $<1.0$ & Zostera marina & - & - \\
\hline \multirow[t]{2}{*}{ Sand/mud } & trawl & 25 & 2.0 & none & $4.5-19.0$ & $26-31$ \\
\hline & seine & 18 & $<1.0$ & none & - & - \\
\hline Sand & trawl & 25 & 3.0 & none & $5.0-18.0$ & $26-34$ \\
\hline Gravel & seine & 18 & $<1.0$ & none & - & - \\
\hline Macroalgal/mud & trawl & 25 & 1.0 & Cladophora sericea & $4.0-19.0$ & $27-31$ \\
\hline Drift algae & trawl & 25 & 5.0 & Gracilaria tikvahiae & $2.0-20.0$ & $24-30$ \\
\hline \multirow[t]{2}{*}{ Water column } & plankton net & 87 & $<1.0$ & none & - & - \\
\hline & nightlight & 24 & surface & none & - & - \\
\hline
\end{tabular}


Several types of gear were used at irregular intervals to augment our regular sampling to obtain a more complete inventory of fishes and decapods. During October 1985 and September 1986 experimental gill nets were deployed overnight in Salt Pond. The dominant fishes were collected, enumerated, measured, and returned to the system. Conical fish traps were deployed occasionally to collect fish at peat reef habitats and from marsh pools. To facilitate comparisons among life history groups and mode of utilization in other northeastern U.S.A. estuaries, we have classified species as either residents (species that spend their entire life span in estuaries), transients (species that spend only a portion of their lives there, typically young-of-the-year), and strays (only occasionally found in estuaries). These designations were based on larger faunal works (Bigelow and Schroeder 1953, Scott and Scott 1988) and our own experience in this (Heck et al. 1989) and other estuarine systems (Able and Fahay 1998).

\section{RESULTS AND DISCUSSION}

\section{Physical characteristics}

All the locations and habitats sampled were similar in temperature and salinity during the sampling period (Table 1). Salinity was consistently high in this polyhaline system. Depth was more variable but almost always $3 \mathrm{~m}$ or less for all habitats with the exception of that for drift algae. Submerged vegetation consisted of dense beds of eelgrass or green algae which occurred on intertidal mudflat habitat. The red alga Gracilaria tikvahiae McLachlan, which was the dominant component of the drift algae habitat, was variable in abundance with extensive accumulations during summer months.

\section{Fish larval supply}

The ichthyoplankton collections occurred at a variety of locations (Fig. 1) and over all seasons during the years sampled. In these collections, 23 species and $>1,300$ individuals were encountered (Table 2). Of these, 16 species were transient forms that either spawned in adjacent oceanic waters (e.g., [Clupea harengus L. (Atlantic herring)] or, occasionally spawned in distant areas and were transported to Cape Cod [(e.g., Anguilla rostrata [Lesueur] (American eel)]. The most abundant residents represented by larvae were Apeltes quadracus (Mitchill) (fourspine stickleback), and Myoxocephalus aenaeus. All of the dominant forms subsequently collected as juveniles were represented. Those not collected, or only rarely so, were resident forms whose larvae occur in very shallow waters [(e.g., Fundulus heteroclitus [L.] (mummichog)]; Fundulus majalis (Walbaum) (striped killifish), or were rarely collected in any life history stage. The species with the most abundant larvae were Ammodytes americanus DeKay (American sand lance), 


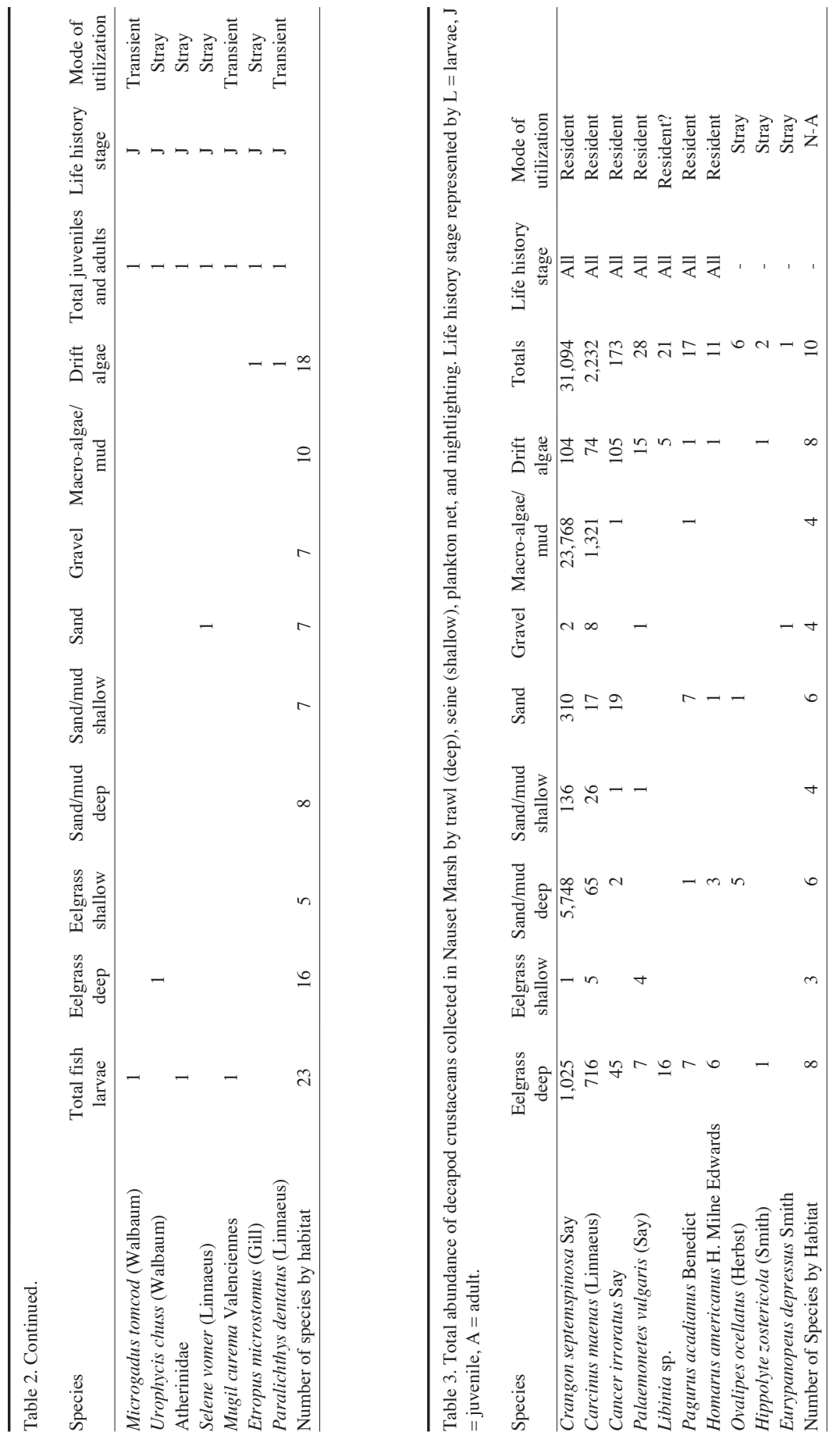


presumably from local spawning, and Anguilla rostrata. The latter was the result of directed night lighting for this species.

\section{Habitat use}

During extensive sampling with a variety of gears in representative habitats we collected $>5,800$ individuals representing 35 species of fishes, and $>33,000$ individuals representing 10 species of decapod crustaceans, during the period from August 1985 through July 1986 when sampling was consistent across all habitats (Table 2, 3). Species richness of fishes varied with habitat (Table 2), and although this measure varied with sampling gear and effort, it provided an indication of habitat use for the composite fauna. Of those habitats sampled by trawl (eelgrass-deep, sand/mud-deep, sand, macroalgae/mud, drift algae), the drift algae (18 species) and eelgrass-deep (18 species) had the greatest species richness. Of those habitats sampled by seine (eelgrass-shallow, sand/mud-shallow, gravel) all were similar in richness (6-8 species). For decapod crustaceans, which were represented by a less-rich fauna relative to fishes, patterns were similar (Table 3), with species richness greatest in drift algae and deep eelgrass (8 species each).

The abundance of fishes and decapods among habitats varied, especially by season, but general habitat specific patterns, based on trawl collections in deeper waters, were evident (Figs. 2, 3). For fishes, the greatest abundance was encountered around June in the drift algae habitat. Abundance was high through the summer in eelgrass, and to a lesser extent in sand/mud, as previously reported (Heck et al. 1989). Abundance in sand and macroalgae/mud was uniformly low during all months. Decapods were generally more abundant in the summer. In sand/mud, abundance was highest in August and October while the macroalgal mudflat was highest in June. The abundance of decapods in eelgrass was highest during June. Sand habitat had the highest abundance in August while abundance in drift algae varied little over the sampling period.

Shallow water seine samples appeared even more strongly seasonal than deep water samples, with very few fish or decapods collected in any habitats during December, April, or June although it should be noted that not every habitat was sampled in every sampling event (Fig. 3). Abundance was highest in eelgrass in August and October but the eelgrass cover was much reduced after that because of seasonal decline which accounts for the lack of individuals in this habitat thereafter. Over sand/ mud substrate fish were abundant in summer (July, August) and early fall (September, October) while decapods, which were largely limited to this habitat type, were most abundant in August and September.

Most species of fish and decapods could be found across a variety of habitats and those that showed fidelity to a single habitat were rare (Table 2,3 ). Of the fishes, several pelagic species were found in many of the 
habitats sampled. These included Menidia menidia (L.) (Atlantic silverside) (6 habitats), Ammodytes americanus (5), Clupea harengus (4), and Gasterosteus aculeatus L. (threespine stickleback) (4). Three species [A. quadracus, Pseudopleuronectes americanus Walbaum (winter flounder), and Syngnathus fuscus Storer (northern pipefish] were found in seven habitats and these were among the most abundant species. Thirteen species were only found in one habitat, primarily because very few individuals were collected. Of the decapods, two species Crangon septemspinosa Say (sevenspine bay shrimp) and Carcinus maenas (L.) (green crab), were found in all eight habitats while Cancer irroratus Say (Atlantic rock crab)

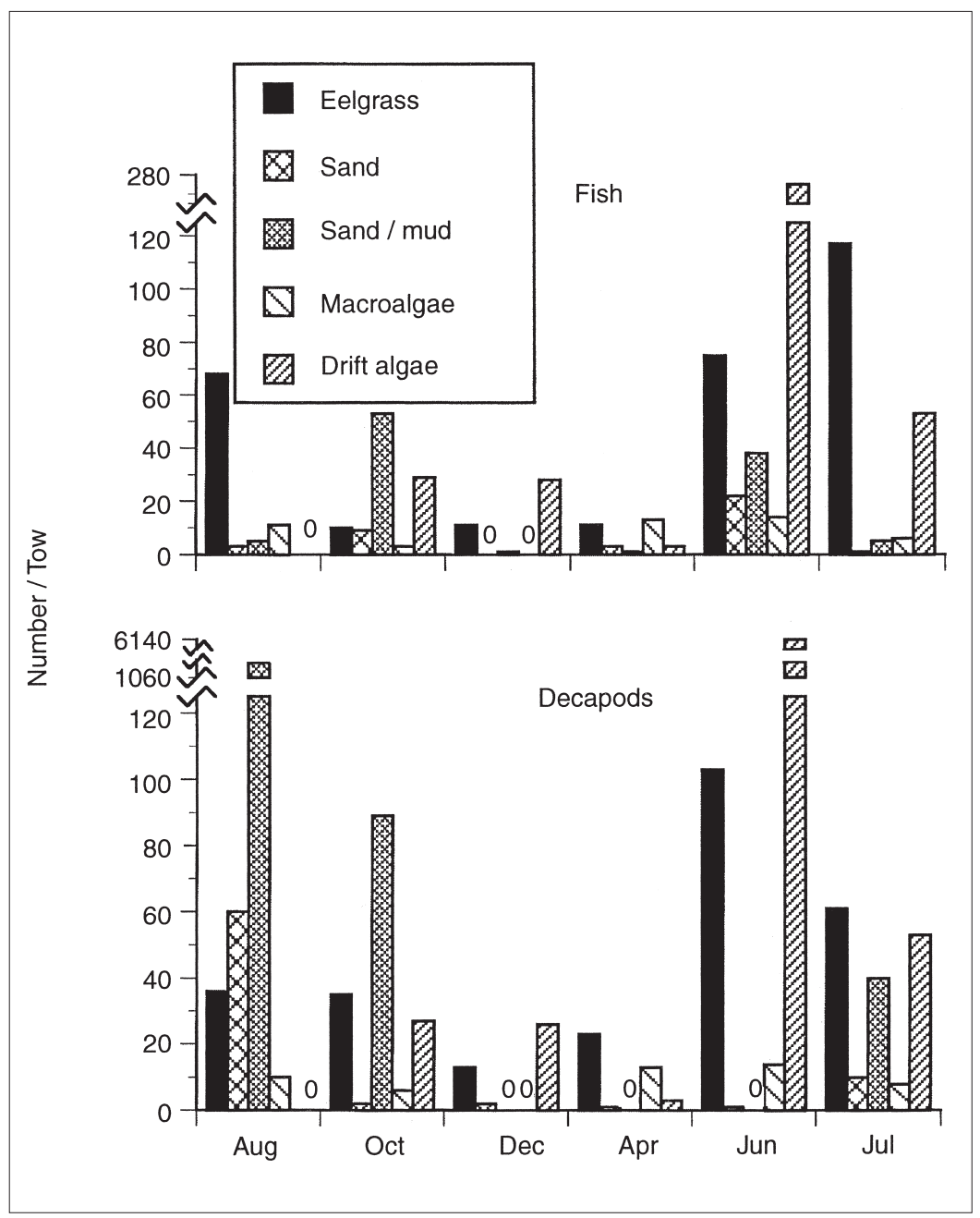

Figure 2. Seasonal variation in fish and decapod crustacean abundance by habitat type based on trawl collections. 
(six habitats), Palaemonetes vulgaris (Say) (marsh grass shrimp), and Pagurus acadianus Benedict (Acadian hermit crab) (five habitats each), were commonly encountered (Table 3).

However, some species clearly used certain habitats more than others. For fishes, several species were more abundant in eelgrass, including sticklebacks with $91 \%$ of the individuals of Gasterosteus aculeatus in deep eelgrass and $85 \%$ of the Apeltes quadracus in deep and shallow eelgrass collections. Myoxocephalus aenaeus (92\%) and Pollachius virens (L.) (pollock) (95\%) were also most abundant in eelgrass. Other

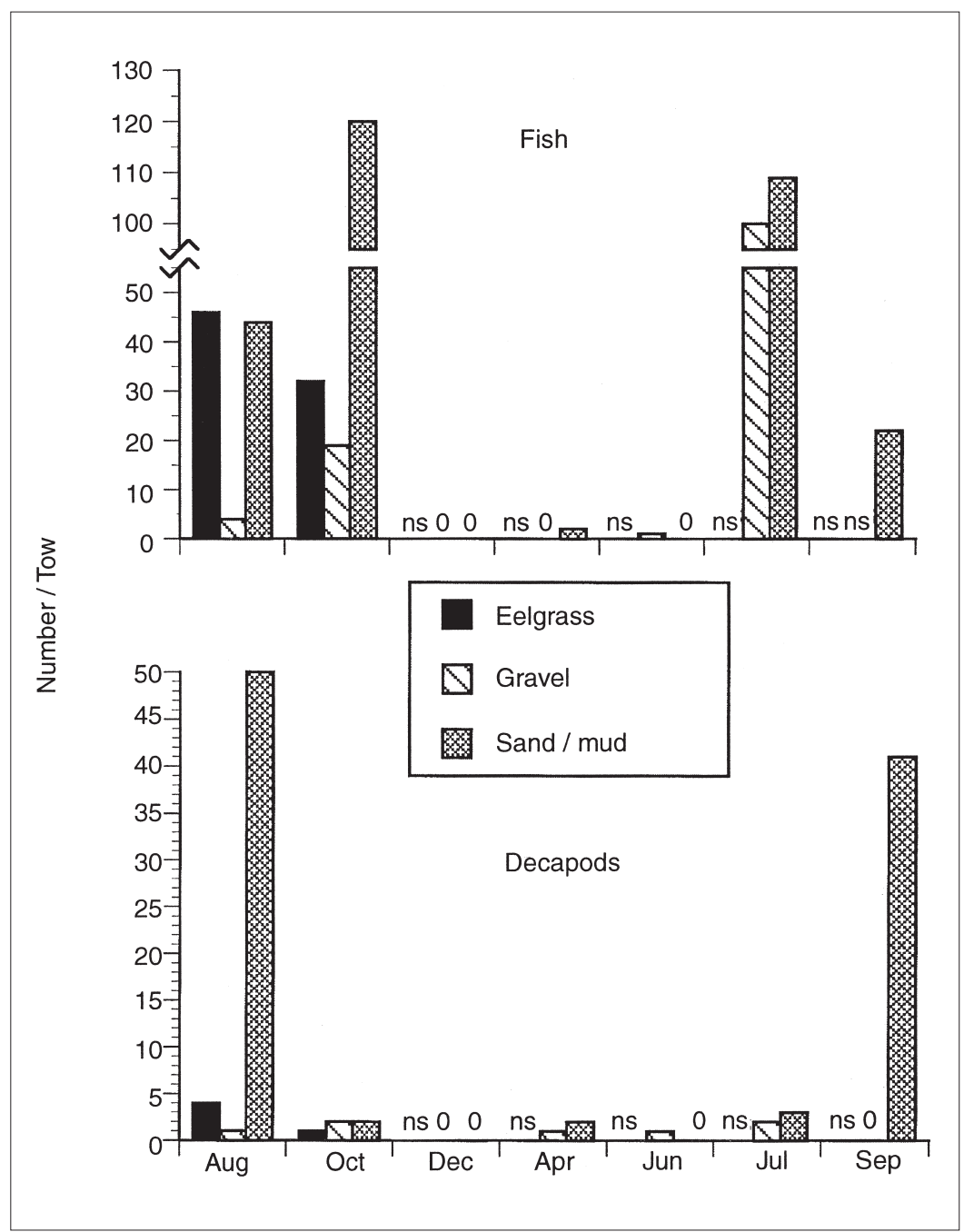

Figure 3. Seasonal variation in fish and decapod crustacean abundance by habitat type based on seine collections. NS = no sample. 
species were found primarily in either eelgrass or drift algae, including Urophycis tenuis (65\% in eelgrass, $35 \%$ in drift algae) and Tautogolabrus adspersus (Walbaum) (cunner) (52\% in eelgrass, 39\% in drift algae). Both of these species were also common around peat reefs, based on diver observations. The preponderance of Clupea harengus $(89 \%)$ in the drift algae habitat (Table 2) most likely reflected the abundance of this pelagic species in the upper ends of the Nauset Marsh system (Town Cove and to some extent Nauset Bay) rather than a preference for vegetation. Other species were collected rather ubiquitously across a variety of habitat types, including Fundulus heteroclitus, Pseudopleuronectes americanus, and Syngnathus fuscus. Curiously, the latter is often assumed to prefer eelgrass or other vegetation (Bigelow and Schroeder 1953). None of the decapods displayed any obvious habitat fidelity (Table 3), however, Crangon septemspinosa (76\%) and Carcinus maenas (59\%) were collected most frequently on macroalgal mudflats, although there may have been reduced gear efficiency for these species in complex habitats such as eelgrass.

\section{Individual Species Accounts}

The following treatments are included for species for which this study provided some new insights into the life history or because they are poorly known from this portion of their range.

Clupea harengus. Young-of-the-year (YOY) individuals apparently use Nauset Marsh as juvenile habitat. A single length mode was apparent in any month. Small juveniles $(20-45 \mathrm{~mm}$ TL) were collected as early as April but no individuals longer than $70-75 \mathrm{~mm}$ were encountered with any of our collecting techniques. These YOY presumably resulted from spawning along outer Cape Cod or on Georges Bank based on numerous collections of larvae in the fall and early winter (Morse et al. 1987).

Pollachius virens. This species represented less than $1 \%$ of the fishes collected but its abundance in Nauset Marsh was probably underestimated because of gear avoidance by this actively swimming pelagic species. Although the numbers are small $(n=30)$, during 1986 the progression in lengths of YOY from $20-30 \mathrm{~mm}$ TL in April to 200$260 \mathrm{~mm}$ by October clearly represented a single year class. This estimate of growth is in agreement with that presented by Haberman and Jensen (1962) but indicates a slightly larger size than observed by Steele (1963) and Clay et al. (1989). Nauset Marsh individuals may have originated from spawning in the nearby Gulf of Maine and Georges Bank (Able and Fahay 1998, Morse et al. 1987).

Apeltes quadracus. This stickleback was the most abundant species collected (Table 2) and a resident of Nauset Marsh based on the yearround abundance of both juveniles $(<30 \mathrm{~mm})$ and adults $(30-60 \mathrm{~mm})$ 
(c.f. Hildebrand and Schroeder 1928). The smallest individuals (20-25 $\mathrm{mm}$ TL) available to our gear appeared in July and August, which is consistent with spring and early summer spawning in the Gulf of Maine (Bigelow and Schroeder 1953).

Gasterosteus aculeatus. This abundant stickleback made up 6.9\% of all fish collected (Table 2). The majority of the adults apparently moved into Nauset Marsh from the continental shelf during spring to spawn as do other Atlantic coast populations (Scott and Scott 1988; Able and Fahay 1998). The young-of-the-year appeared in samples by July at approximately $15-30 \mathrm{~mm}$ TL. At this time, the adults were much fewer in number and both juveniles and adults were rare by August. We suspect that this decline in numbers is due to the mortality of adults after spawning and the migration of juveniles out of the marsh to the continental shelf as occurs in the Mid-Atlantic Bight (Able and Fahay 1998, Cowen et al. 1991) although a few individuals were present during every collecting period.

Ammodytes americanus. This abundant species was not always well represented in our collections, presumably due to gear avoidance. Observations of large pelagic schools by divers and from the surface were common and juveniles (approximately $100 \mathrm{~mm}$ TL) were occasionally taken in benthic suction samples (Heck et al. 1995) where densities ranged as high as $8 \mathrm{~m}^{-2}$. Aspects of the life history of this species are not well known because of taxonomic confusion with the offshore form Ammodytes dubius Reinhardt, northern sand lance. The identity of our specimens was validated as part of a study by Nizinski et al. (1990). Spawning presumably occurs in late winter or early spring because recently hatched larvae $(<10 \mathrm{~mm}$ TL) were collected in April. Additional collections suggested that they reach approximately $40-120 \mathrm{~mm}$ by October of the first year, the same approximate size found in New Jersey waters (Able and Fahay 1998).

Pseudopleuronectes americanus. At least some life history stage of this species appeared to be resident in Nauset Marsh the entire year, in a manner similar to that for other populations in Massachusetts coastal waters (Howe and Coates 1975). Recently hatched larvae $(<10 \mathrm{~mm}$ TL) from a winter spawning were collected in April. This cohort was represented by $30-90 \mathrm{~mm}$ individuals in July and August and $30-100 \mathrm{~mm}$ in October, which is similar to the size range reported by Bigelow and Schroeder (1953). They apparently do not grow much over the winter based on a 50-100 mm cohort observed in April samples. These and other one-year-old fish appeared as well-defined modes in June (80$150 \mathrm{~mm})$ and July $(120-160 \mathrm{~mm})$.

Several other fish species were well represented as juveniles and adults in our summer collections (Table 2). Syngnathus fuscus $(20-250$ 
mm TL) was abundant but apparently moved offshore during the colder months (Lazzari and Able 1990). Tautogolabrus adspersus was more abundant than our collections indicated because individuals were consistently observed by divers around peat reefs where they were unavailable to trawls and seines. Young-of-the-year $(25-70 \mathrm{~mm}$ TL) were abundant in October presumably as a result of summer spawning, based on the timing of spawning in Connecticut (Dew 1976) and the summer occurrence of larvae in adjacent offshore areas (Morse et al. 1987). Adult Brevoortia tyrannus (Latrobe), adult menhaden, taken in September 1986 had maturing gonads, which would agree with the fall spawning period reported for more northern areas (Ahrenholz et al. 1987) based on the occurrence of larvae in New England waters at that time (Morse et al. 1987). Juveniles ( $80-100 \mathrm{~mm}$ TL) were collected in September and October with gill nets and were observed in large schools during the same period. Menidia menidia probably spawn in Nauset Marsh. Juveniles were collected in July and October and then presumably moved offshore with the adults for the winter as occurs for other Massachusetts populations (Conover and Murawski 1982). Fundulus heteroclitus is a resident of Nauset Marsh, with several age classes represented in the collections based on modal lengths $(20-45,60-85$, $110-120 \mathrm{~mm}$ TL). Other species that are resident or use the area as juvenile habitat have been discussed elsewhere including Myoxocephalus aenaeus (Lazzari et al. 1989), Homarus americanus (Able et al. 1988), and Urophycis tenuis (Fahay and Able 1989).

The dominant decapod crustaceans appear to be resident. Crangon septemspinosa appeared to be a year-round resident with juveniles and adults of typical sizes (15-50 mm) (Haefner 1979) present in almost all collections. Carcinus maenas was also resident with the smallest individuals $(5 \mathrm{~mm} \mathrm{CW})$ present in October and adults present in almost every collection.

\section{Faunal Composition of Nauset Marsh}

The fish and decapod fauna of Nauset Marsh owes its origins to a variety of sources. Of the fishes, five species (14\%) are considered resident, and $18(51 \%)$ are categorized as transient species. The remainder (strays) were all represented by fewer than 10 individuals. For the decapods, there were seven $(70 \%)$ resident species and three $(30 \%)$ stray species.

Transient and resident species numerically dominated the fish fauna, comprising approximately $65.6 \%$ and $33.6 \%$, respectively, while residents made up $99.9 \%$ of the decapod fauna. The distinction between residents and transient species is not clear for all components of the fauna. For example, Teal (1986) considered Menidia menidia and Gasterosteus aculeatus in Great Sippewisset Marsh, MA, to "spend most of their lives within the marsh." However, both species spawn in 
the marsh and produce young-of-the-year that migrate offshore in the fall (Conover and Murawski 1982) or early in the summer (Cowen et al. 1991). For others, such as Pseudopleuronectes americanus, at least some portion of the population is resident year-round, but there is a migratory component as well, in this case the adults.

In general, however, it appears that all of the most abundant species of fishes and all of the decapod species collected in Nauset Marsh use it as habitat for young-of-the-year. Of these, $30 \%$ of the fish species are economically important in commercial or recreational fisheries. This estimate for commercial species is similar to the $32 \%$ (by weight) of estuarine-dependent species estimated for the northeastern United States (Chambers 1992). For decapod crustaceans, only Homarus americanus and Cancer irroratus are commercially important. These comprised $20 \%$ of the total species and $0.5 \%$ of the total number of individual decapods collected.

These results expand on some aspects of a previous faunal investigation in Nauset Marsh that focused on the eelgrass habitat (Heck et al. 1989). First, the significance of Nauset Marsh as a habitat for juveniles broadens considerably when other habitats, besides eelgrass, are considered. For example, Nauset Marsh can be considered juvenile habitat for Homarus americanus, Clupea harengus, Brevoortia tyrannus, Ammodytes americanus, Anguilla rostrata, Tautogolabrus adspersus, Carcinus maenas, and Cancer irroratus as a result of the inclusion of more habitats in our evaluation. Second, species richness for the estuary is enhanced by the addition of two decapods (Table 3 ) and 13 generally rare fishes from these additional habitats (Table 2).

The composition of the fish fauna generally reflects the location of Nauset Marsh on Cape Cod, which is at the junction of two zoogeographic provinces (Ayvazian et al. 1992, Grosslein and Azarovitz 1982, Parr 1933). A northern, or boreal fauna, was well represented in Nauset Marsh by numerous cold water forms (e.g., Clupea harengus, Gadus morhua L. (Atlantic cod), Pollachius virens, and Pholis gunnellus (L.) (rock gunnel), while southern components are represented by such forms as Fundulus majalis, Menidia beryllina (Cope) (inland silverside), and numerous southern transients that occurred only rarely, Anchoa mitchilli (Valenciennes), bay anchovy, Anchoa hepsetus (L.), striped anchovy, Peprilus triacanthus (Peck), butterfish, Mugil curema Valenciennes, white mullet, Paralichthys dentatus (L.), summer flounder. The southern transients were collected during late summer when water temperatures peaked. The fish fauna of Nauset Marsh was similar to Waquoit Bay, Massachusetts, based on the recent study by Ayvazian et al. (1992). At Nauset Marsh, 79\% of the species were shared with Waquoit Bay, compared with Wells Harbor, Maine (Ayvazian et al. 1992), where only $50 \%$ of the species were in common (see also Targett and McCleave 1974). 
The broad zoogeographic influences of Cape Cod on faunal composition as frequently recognized (Ayvazian et al. 1992, Grosslein and Azarovitz 1982, Parr 1933) may be evident on a smaller, local scale in Cape Cod estuaries. Many species that did not occur, or occurred only rarely, in our sampling Pomatomus saltatrix (L.) (bluefish), Caranx hippos (L.) (crevalle jack), Centropristis striata (L.) (black sea bass), Prionotus carolinus (L.) (northern searobin), Lucania parva (Baird and Girard) (rainwater killifish), Stenotomus chrysops (L.) (scup), and Sphoeroides maculatus (Bloch and Schneider) (northern puffer), were more important components of the fauna of Cape Cod estuaries located to the south of Nauset Marsh (Curley et al. 1975a, Curley et al. 1975b, Hoff and Ibara 1977, Mulkana 1966). In addition, several southern fishes that have been collected from Pleasant Bay (Fiske et al. 1967; Fig. 1), immediately to the south, did not occur at Nauset Marsh, including Opsanus tau (L.) (oyster toadfish), Strongylura marina (Walbaum) (Atlantic needlefish), Cyprinodon variegatus Lacepède (sheepshead minnow) (although the latter was collected previously from Nauset Marsh; H. Linde, pers. comm.), and Trinectes maculatus (Bloch and Schneider) (hogchoker) (Fiske et al. 1967, Sargent 1981). Also, Callinectes sapidus Rathbun (blue crab), a southern decapod species that was observed at Nauset Marsh only as a result of an apparent "fish kill" in Salt Pond Bay, was known to occur commonly in Pleasant Bay and in some years was even abundant. These differences may be related to inlet location. Nauset Marsh opens directly to the Atlantic Ocean, and is probably influenced largely by the prevailing southerly flow of cold water from the Gulf of Maine (Bigelow and Schroeder 1953). The inlet to Pleasant Bay, however, opened on the southern side of the Cape Cod "elbow" at the times of prior surveys (Fiske et al. 1967, Sargent 1981), where an easterly flow of warmer water from Nantucket Sound (Limeburner and Beardsley 1982) may have provided for the dispersal of more southerly components of the fauna along the coast to the north and east. A test of the relationship between estuarine faunal composition and temperature effects on Cape Cod may now be possible due to a storm (1988) that shifted the major Pleasant Bay inlet eastward to a position facing the Atlantic Ocean. Among other effects, colder ocean water may now dominate at Pleasant Bay and, if our observations are correct, we predict that the fauna will have fewer southern forms and will appear more like that of Nauset Marsh in future surveys.

In summary, a variety of habitat types contribute as juvenile habitat for resident and transient fishes and decapods in Nauset Marsh, but vegetated habitats (eelgrass and macroalgae) had the highest values for species richness. The location of Nauset Marsh and other estuaries on the outer portion of Cape Cod provide a unique opportunity to evaluate the impacts of this region as a faunal boundary for estuarine species. 


\section{ACKNOWLEDGMENTS}

Barbara Baker and Terry Westhead assisted in data gathering and analysis. Capt. H. Morgan of the R/V Ursula assisted in many aspects of this study. Henry Linde shared his notes on the fauna of the estuary. Richard McBride provided comments on an earlier draft. The National Park Service, through the Cooperative Research Unit, the Institute of Marine and Coastal Studies (IMCS) at Rutgers University, and the National Marine Fisheries Service, Sandy Hook Laboratory provided support for this study. This is Rutgers University IMCS Contribution Number 2002-17.

\section{LITERATURE CITED}

ABLE, K.W., and M.P. FAHAY. 1998. The First Year in the Life of Estuarine Fishes in the Middle Atlantic Bight. Rutgers University Press, New Brunswick, NJ. 342 pp.

ABLE, K.W., K.L. HECK, Jr., M.P. FAHAY, and C.T. ROMAN. 1988. Use of saltmarsh peat reefs by small juvenile lobsters on Cape Cod, Massachusetts. Estuaries 11(2):83-86.

AHRENHOLZ, D.W., W.R. NELSON, and S.P. EPPERLY. 1987. Population and fishery characteristics of Atlantic menhaden, Brevoortia tyrannus. Fishery Bulletin U.S. 85(3):569-600.

AUBREY, D.G., and P.E. SPEER. 1985. A study of non-linear tidal propagation in shallow inlet/estuarine systems. Part I: observations. Estuarine Coastal and Shelf Science 21:185-205.

AYVAZIAN, S.G., L.A. DEEGAN, and J.T. FINN. 1992. Comparison of habitat use by estuarine fish assemblages in the Acadian and Virginian provinces. Estuaries 15(3):368-383.

BIGELOW, H.B., and W.C. SCHROEDER. 1953. Fishes of the Gulf of Maine. U.S. Fish and Wildlife Service, Fishery Bulletin U.S. 74(53): 1 - 576.

CHAMBERS, J.R. 1992. Coastal degradation and fish population losses. Pp. 4551, In R.H. Stroud (Ed.), Stemming the Tide of Coastal Fish Habitat Loss. Marine Recreational Fisheries Symposium, Proceedings of the National Symposium on Fish Habitat Conservation, Baltimore, MD.

CLAY, D., W.T. STOBO, B. BECK, and P.C.F. HURLEY. 1989. Growth of juvenile pollock (Pollachius virens L.) along the Atlantic coast of Canada with inferences of inshore-offshore movements. J. of Northwest Atlantic Fisheries Science 9:37-43.

CONOVER, D.O., and S.A. MURAWSKI. 1982. Offshore winter migration of the Atlantic silverside, Menidia menidia. Fishery Bulletin, U.S. 80:145-150.

CONOVER, D.O., and M.R. ROSS. 1982. Patterns in seasonal abundance, growth and biomass of the Atlantic silverside, Menidia menidia, in a New England estuary. Estuaries 5:275-286.

COWEN, R.K., L.A. CHIARELLA, C.J. GOMEZ, and M.A. BELL. 1991. Offshore distribution, size, age, and lateral plate variation of late larval/early juvenile sticklebacks (Gasterosteus) off the Atlantic coast of New Jersey and New York. Canadian Journal of Fisheries and Aquatic Sciences 48:1679-1684.

CURLEY, J.R., K.E. REBACK, D.L. CHADWICK, and R.P. LAWTON. 1975a. A study of the marine resources of Bass River. Commonwealth of Massachusetts, Division of Marine Fisheries Monograph Series No. 16.

CURLEY, J.R., K.E. REBACK, D.L. CHADWICK, and R.P. LAWTON. 1975b. A study of the marine resources of the Waquoit Bay-Eel Pond Estuary. Commonwealth of Massachusetts, Division of Marine Fisheries Monograph Series No. 9.

DEW, C.B. 1976. A contribution to the life history of the cunner, Tautogolabrus adspersus, in Fishers Island Sound, CT. Chesapeake Science 17(2):101-113. 
FAHAY, M.P., and K.W. ABLE. 1989. White hake, Urophycis tenuis, in the Gulf of Maine: spawning seasonality, habitat use and growth in young of the year and relationships to the Scotian Shelf population. Canadian Journal of Zoology 67:1715-1724.

FISKE, J.D., C.E. WATSON, and P.G. COATES. 1967. A study of the marine resources of Pleasant Bay. Commonwealth of Massachusetts, Division of Marine Fisheries Monograph Series No. 5.

GROSSLEIN, M.D., and T.R. AZAROVITZ. 1982. Fish Distribution. MESA New York Bight Atlas Monograph. 15.

HABERMAN, J.M., and A.C. JENSEN. 1962. The growth rate of New England pollock. Transactions of the American Fisheries Society 91:227-228.

HAEDRICH, R.L., and S.O. HAEDRICH. 1974. A seasonal survey of the fishes in the Mystic River, a polluted estuary in downtown Boston, Massachusetts. Estuarine Coastal and Marine Science 2:59-73.

HAEFNER, P.A., Jr. 1979. Comparative review of the biology of North Atlantic Canadian shrimps (Crangon), with emphasis on C. septemspinosa. Bulletin of the Biological Society of Washington 3:1-40.

HECK, K.L., JR., K.W. ABLE, M.P. FAHAY, and C.T. ROMAN. 1989. Fishes and decapod crustaceans of Cape Cod eelgrass meadows: Species composition, seasonal abundance patterns and comparison with unvegetated substrates. Estuaries 12(2):59-65.

HECK, K.L., JR., K.W. ABLE, C.T. ROMAN, and M.P. FAHAY. 1995. Composition, abundance, biomass, and production of macrofauna in a New England estuary: comparisons among eelgrass meadows and other nursery habitats. Estuaries 18(2):379-389.

HILDEBRAND, S.F., and W.C. SCHROEDER. 1928. Fishes of the Chesapeake Bay. U.S. Bureau of Fisheries 53(1):388 pp.

HOFF, J.G., and R.M. IBARA. 1977. Factors affecting the seasonal abundance, composition and diversity of fishes in a southeastern New England estuary. Estuarine, Coastal and Marine Science 5:665-678.

HOWE, A.B., and P.G. COATES. 1975. Winter flounder movements, growth, and mortality off Massachusetts. Transactions of the American Fisheries Society 104(1):13-29.

JEFFRIES, H.P., and W.C. JOHNSON. 1974. Seasonal distributions of bottom fishes in the Narragansett Bay area: seven-year variations in the abundance of winter flounder (Pseudopleuronectes americanus). Journal of the Fisheries Research Board of Canada 31(6):1057-1066.

LAZZARI, M.A., and K.W. ABLE. 1990. Northern pipefish, Syngnathus fuscus, occurrences over the Mid-Atlantic Bight continental shelf: Evidence of seasonal migration. Environmental Biology of Fishes 27:177-185.

LAZZARI, M.A., K.W. ABLE, and M.P. FAHAY. 1989. Life history and food habits of the grubby, Myoxocephalus aenaeus (Cottidae), in a Cape Cod estuary. Copeia 1:7-12.

LAZZARI, M.A., and B. TUPPER. 2002. Importance of shallow water habitats for demersal fishes and decapod crustaceans in Penobscot Bay, Maine. Environmental Biology of Fishes 63: 57-66.

LIMEBURNER, R., and R.C. BEARDSLEY. 1982. The seasonal hydrography and circulation over Nantucket Shoals. Journal of Marine Research 40(suppl):371-406.

McHUGH, J.L. 1966. Management of estuarine fishes. American Fisheries Society Special Publication 3:133-154. 
MORSE, W.W., M.P. FAHAY, and W.G. SMITH. 1987. MARMAP survey of the continental shelf from Cape Hatteras, North Carolina, to Cape Sable, Nova Scotia (1977-1984). Atlas No. 2. Annual distribution patterns of fish larvae. NOAA Technical Memorandum NMFS-F/NEC-47.

MULKANA, M.S. 1966. The growth and feeding habits of juvenile fishes in two Rhode Island estuaries. Gulf Research Reports 2:97- 167.

NIXON, S.W. 1982. The ecology of New England high salt marshes; A community profile. U.S. Fish and Wildlife Service FWS/OBS-81/58. 70 pp.

NIZINSKI, M.S., B.B. WASHINGTON, and B.B. COLLETTE. 1990. Separation of two species of sand lances, Ammodytes americanus and A. dubius in the Western North Atlantic. Fishery Bulletin U.S. 88(2):241-256.

OVIATT, C.A., and S.W. NIXON. 1973. The demersal fish of Narragansett Bay: an analysis of community structure, distribution and abundance. Estuarine and Coastal Marine Science 1:361-378.

PARR, A.E. 1933. A geographical-ecological analysis of the seasonal changes in temperature conditions in shallow water along the Atlantic coast of the United States. Occasional Papers of the Bingham Oceanographic Collection 4(3):1-90.

PEARCY, W.G., and S.W. RICHARDS. 1962. Distribution and ecology of fishes of the Mystic River Estuary, Connecticut. Ecology 43(2):248 - 259.

PORTNOY, J.W., B.L. NOWICKI, C.T. ROMAN, and D.W. URISH. 1998. The discharge of nitrate-contaminated groundwater from developed shoreline to marsh-fringed estuary. Water Resources Research 34:3095-3104.

ROMAN, C.T., and K.W. ABLE. 1988. Production ecology of eelgrass (Zostera marina L.) in a Cape Cod salt marsh-estuarine system, Massachusetts. Aquatic Botany 32:353-363.

ROMAN, C.T., K.W. ABLE, M.A. LAZZARI, and K.W. HECK, Jr. 1990. Primary productivity of angiosperm and macroalgae dominated habitats in a New England salt marsh: a comparative analysis. Estuarine Coastal and Shelf Sciences. 30:35-45.

ROUNTREE, R.A., and K.W. ABLE. 1992. Fauna of polyhaline subtidal marsh creeks in southern New Jersey: Composition, abundance and biomass. Estuaries 15(21): $171-185$.

ROUNTREE, R.A., and K.W. ABLE. 1993. Diel variation in decapod crustacean and fish assemblages in New Jersey polyhaline marsh creeks. Estuarine Coastal and Shelf Sciences 37:181-201.

SARGENT, W. 1981. Shallow Waters: A Year on Cape Cod's Pleasant Bay. Houghton Mifflin Co., Boston, MA. 138 pp.

SCOTT, W.B., and M.G. SCOTT. 1988. Atlantic Fishes of Canada. Canadian Bulletin of Fisheries and Aquatic Sciences 219: 731 pp.

STEELE, D.H. 1963. Pollock (Pollachius virens (L) in the Bay of Fundy. Journal of the Fisheries Research Board of Canada 20:1267-1314.

TARGETT, T.E., and J.D. McCLEAVE. 1974. Summer abundance of fishes in a Maine tidal cove with special reference to temperature. Transactions of the American Fisheries Society 103(2):325 - 330.

TEAL, J.M. 1986. The ecology of regularly flooded salt marshes of New England: A community profile. U.S. Fish and Wildlife Service Biological Report 85(7.4). $61 \mathrm{pp}$.

UNDERWOOD, A.J., M.G. CHAPMAN, and S.D. CONNELL. 2000. Observations in ecology: you can't make progress on processes without understanding the patterns. Journal of Experimental Marine Biology and Ecology 250:97 - 115.

WERME, C.E. 1981. Resource partitioning in a salt marsh fish community. Ph.D. Thesis, Boston University, Boston, MA. 126 pp. 